\title{
Insect flower visitors of planted native species within the arable landscape on the Canterbury Plains, New Zealand
}

\author{
Franziska G. Schmidlin ${ }^{1, *}$, Jon J. Sullivan ${ }^{1}$, Mike H. Bowie ${ }^{1}$ and Brad G. Howlett ${ }^{2}$ \\ ${ }^{1}$ Agriculture and Life Sciences Division, Lincoln University, PO Box 84, Lincoln 7647, New \\ Zealand \\ ${ }^{2}$ The New Zealand Institute for Plant \& Food Research Limited (PFR), Private Bag 4704, \\ Christchurch Mail Centre, Christchurch 8140, New Zealand \\ *Corresponding author: Franziska.Schmidlin@lincolnuni.ac.nz
}

\begin{abstract}
Almost all of the original native vegetation of Canterbury Plains has been replaced with an arable landscape of managed exotic vegetation. A previous study planted small areas of native trees on arable farms in 2013 to enhance the abundance and diversity of beneficial insect crop pollinators. The aim of the current study was to assess insect flower visitation at three sites in the fifth year after planting. Weekly standardised surveys of native flower visitors were conducted between September 2017 and February 2018. A total of 2349 insects from 37 taxa were observed within three native plantings. Native bees (Lasioglossum sordidum 20\%) and the honey bee, Apis mellifera (19\%), were the most common followed by the large hoverfly, Melangyna novaezelandiae (16\%). The calliphorid flies, brown blowfly Calliphora stygia (8\%) and blue blowfly Calliphora vicina (6\%), were also well represented. The most abundant insects visited four or more of the eight study plant species. Most (52\%) of the flower visitors where natives. Many of these insects are known crop pollinators and it is likely that they assist with crop pollination.
\end{abstract}

Keywords: agriculture, ecosystem services, pollination, native restoration, semi-natural habitats, pollinator resource, crop pollination.

\section{INTRODUCTION}

Little is known about the importance of perennially flowering woody vegetation in supporting pollinating insects in New Zealand (Howlett et al 2013a) but such vegetation is known to support arthropod biodiversity (Fukuda et al. 2011). Intensively farmed, largescale arable landscapes areas are dominated by single mass-flowering crops resulting in large fluctuations in floral resources during the season. Stavert et al. (2018) showed that agricultural intensification can increase exotic pollinators (mainly Eristalis tenax) and compensate for the loss of native pollinators. However, it is a biodiverse pollinator composition that supports a wider range of crops and makes pollination services more resilient to environmental change (Rader et al. 2013). The Canterbury Plains has undergone significant agricultural intensification since European settlement and is currently dominated by livestock (particularly dairy) and arable farming (Dynes et al. 2010) notably oilseed rape, other brassicas, clover, onions, carrots, radishes as well as wind-pollinated grains and grasses. In such environments, the high variation in floral resource availability for pollinators is thought to make it difficult for large wild populations of pollinators to persist (Dicks et al. 2015). Furthermore, the widespread use of pesticides and herbicides associated with 
agricultural intensification and the paucity of semi-natural habitats can also impact ecosystem service providers like insect pollinators (Morandin \& Kremen 2013) and insect pest regulators (Davidson et al. 2015; Fontaine et al. 2006).

With the worldwide decline of honey bee populations, thought to be due to a combination of habitat loss, agrochemicals, pathogens and climate change (Potts et al. 2010), the future regarding long-term crop-pollination service is uncertain. It is risky to rely on a single species to pollinate crops and produce food (Klein et al. 2007; Potts et al. 2010). Preserving landscapes that support wild pollinator populations can be regarded as an important, and prudent, insurance against potential failures in crops pollinated predominantly by honey bee (and bumble bee) populations. Native or semi-native habitats within agricultural landscapes can increase wild bee populations (Jauker et al. 2009; Lentini et al. 2012; Ponisio et al. 2016; Venturini et al. 2017). This can support increased yields or yield consistency due to their complementarity with pollination services, for example through diversifying pollen transfer pathways (Garibaldi et al. 2013), differing activity patterns under variable weather conditions (Howlett et al. 2013a) or seasonal activity (Howlett et al. 2016). In a recent analysis of 39 studies conducted in several countries across different continents, Rader et al. (2016) highlighted the significant role that non-bee insect pollinators play in global crop production. A diversity of insect species (both bees and non-bees) visit the flowers of arable crops on the Canterbury Plains. These crops include pak choi Brassica rapa subsp. chinensis (Howlett et al. 2009), onion Allium cepa (Howlett et al. 2005), carrot Daucus carota subsp. sativus (Howlett et al. 2015), and radish Raphanus ativus (Howlett et al. 2013b). Native bees, bumblebees and several fly species have been verified as pollinators of pak choi (Howlett et al. 2011; Rader et al. 2009), onion (Howlett et al. 2017), carrot (Howlett 2012) and other vegetable seed fields in Canterbury (B. Howlett unpublished data).
To determine whether native plantings on arable farms support pollinator diversity the current study, conducted over an entire summer season, documented insect flower visitors on eight native tree species planted on three farms. This information is required to assess whether such plantings can assist in supporting a diversity of known arable crop pollinators.

\section{METHODS}

\section{Study system}

Three farms within $50 \mathrm{~km}$ of Rakaia, Canterbury ( $43^{\circ} 33^{\prime} 56^{\prime \prime} \mathrm{S}, 171^{\circ} 41^{\prime} 35^{\prime \prime}$ E, $7 \mathrm{~m}$ above sea level, $43^{\circ} 53^{\prime} 39^{\prime \prime} \mathrm{S}, 171^{\circ} 50^{\prime} 46^{\prime \prime} \mathrm{E}, 21 \mathrm{~m}$, and $43^{\circ} 53^{\prime}$ $32^{\prime \prime} \mathrm{S}, 172^{\circ} 06^{\prime} 55^{\prime \prime} \mathrm{E}, 172 \mathrm{~m}$ ) were assessed. All three conventionally managed farms had native biodiverse plantings established in October 2013 as part of a project funded by the Foundation for Arable Research and the Sustainable Farming Fund. All plantings are located in the vicinity of crop fields. In 2017/2018, the adjacent crops were seed crops of ryegrass Lolium perenne, mustard Sinapis alba, red clover Trifolium pratense, and flax Linum usitatissimum. Spacing between seedlings within the native plantings was $1.5 \mathrm{~m}$ $\mathrm{x} 1.5 \mathrm{~m}$ throughout. The plantings were between $300 \mathrm{~m}^{2}$ and $440 \mathrm{~m}^{2}$ and each consisted of $30-34$ species, including 26 species that were shared across all sites. Eight of these shared species (see Table 1) were in bloom the season before and could, therefore, be tagged as study specimens. The plantings were divided into six sections of even size, the midpoint of each section was selected, then the closest tree to the midpoint of the given species was chosen as marked specimen. Each marked specimen was visited and, if in bloom ( $>20 \%$ open flowers per bush), observed weekly. One of the three farms had an apiary of 24 honey-bee colonies permanently placed at the edge of the native planting.

\section{Flower visitor surveys}

Between September 2017 and February 2018, insect observation surveys were conducted weekly on the eight chosen native plant species. Two-minute surveys of flower visitors were conducted on the north and south side of each 
plant. Each week, the order of farm visits was altered. This resulted in varied observation times between 9:00 and 15:00. Observations were not made unless the wind speed was less than $15 \mathrm{~km} / \mathrm{h}$, temperature was higher than $12^{\circ} \mathrm{C}$ and no rainfall was occurring.

Each landing of an insect on an open flower was recorded. Insect identifications was made by one to two researchers trained to recognise the known insect pollinators and common flower visitors. Where possible, unknown flower visitors were caught and identified later. Most visitors could be identified to species or genus. Tiny insects $(<3 \mathrm{~mm})$ such as thrips were not recorded nor collected as they have not been shown to be significant pollinators of pak choi (Walker et al. 2009) or onion (Walker et al. 2011) and their importance as pollinators in other crops has not been assessed in New Zealand.

As the focus of this study was to identify the flower-visiting species associated with the established native plants on arable farms and their occurrence across the plant species, formal statistical analyses were not considered necessary to achieve this aim.

\section{RESULTS}

A total of 2,349 flower visiting insects were counted in the biodiverse plantings across the three arable farms (Table 1). Bio-status could be assigned unambiguously to $97 \%$ of the insects; $52.0 \%$ of these were natives. The eight most abundant flower visitors, that made up $80.4 \%$ of all visitors, were, in decreasing abundance, Lasioglossum sordidum (native Halictidae), Apis mellifera (exotic Apidae), Melangyna novaezelandiae (native Syrphidae), Calliphora stygia (exotic Calliphoridae), Calliphora vicina (exotic Calliphoridae), Leioproctus species (native Colletidae, a mix of L. pango, L. boltoni, and L. fulvescens), Odontomyia spp. (native Stratiomyidae), and Eristalis tenax (exotic Syrphidae) (Table 1).

Of the flower visitors, honey bees (Apis mellifera) was not always the most abundant nor generalist pollinator observed (Table 1).
Lasioglossum bees were as abundant as honey bees overall and more abundant on some flowers. The hoverfly Melangyna novaezelandiae was the only insect observed visiting all eight tree species. Bees and wasps (Hymenoptera) in total comprised $45.8 \%$ of the total flower visitors with flies (Diptera) representing 52.4\% (Table $1)$. The remainder were Lepidoptera (1.3\%) and Coleoptera $(0.6 \%)$ although all surveys were diurnal and so did not account for potential nocturnal insect activity. Unexpectedly, the site with nearby honey-bee hives, did not contain the highest $A$. mellifera count but did, however, show 50\% more Lasioglossum spp. than Apis mellifera.

The most abundant flower visitors were seen at four or more of the eight tree species surveyed, with four insect taxa visiting 7-8 tree species (Table 1). All of these insects could be considered generalist flower visitors as the eight trees represent a range of plant families and floral structures. However, even among the most generalist insect pollinators (generalists visit several plant species (Maldonado et al. (2013)), some tree species appeared to be favoured. For example, while Leioproctus bees visited seven of the eight tree species, most of these visits were to Carmichaelia australis (45.1\%) or Veronica salicifolia (41.2\%). In contrast, while Melangyna novaezelandiae visited all tree species, most visits were to Ozothamnus leptophyllus (40.4\%) or Leptospermum scoparium (27.2\%).

Most tree species attracted a variety of insect flower visitors, from five (Carmichaelia australis) to 25 (Veronica salicifolia) insect taxa (Table 1). Flies dominated the flower visitors for some tree species, especially Leptospermum scoparium (87.7\% Diptera), Ozothamnus leptophyllus (78.8\% Diptera), Cordyline australis (71.4\% Diptera), and Kunzea serotina (71.0\% Diptera). In contrast, bees and wasps dominated the visitors to Carmichaelia australis (94.9\% Hymenoptera), Veronica salicifolia (72.3\% Hymenoptera), and Phormium tenax (70.6\% Hymenoptera). Discaria toumatou visitors were $55.2 \%$ Hymenoptera and 43.8\% Diptera. 


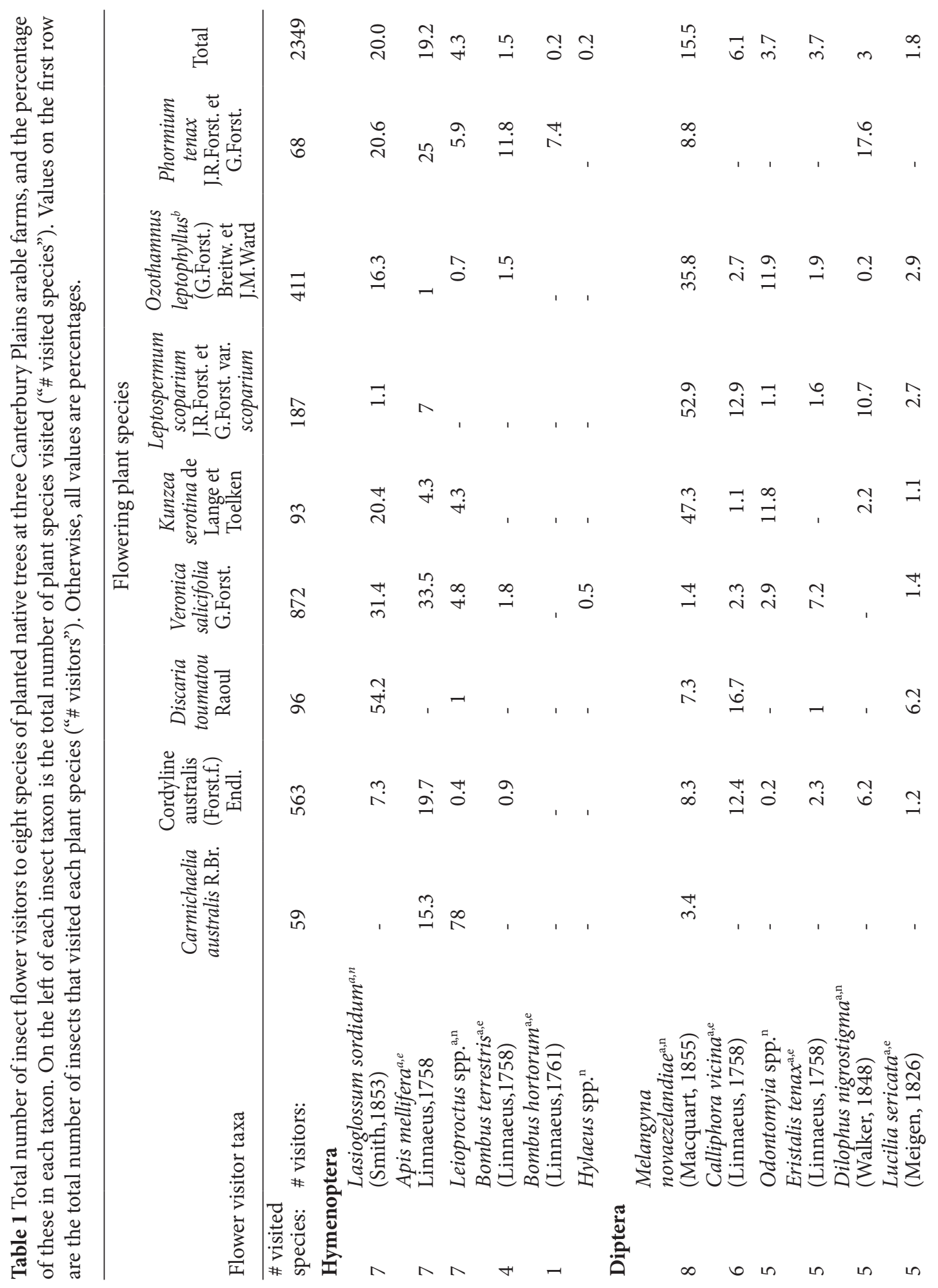




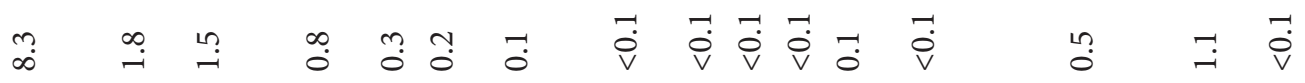

$$
\begin{aligned}
& \text { 공 } \\
& \text { 옹 둥 궁 궁 } \\
& \text { ำ } \\
& \stackrel{\infty}{+} \\
& \text { !n } \\
& \text { I สี } \\
& \stackrel{0}{3} \div 3
\end{aligned}
$$

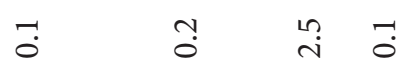

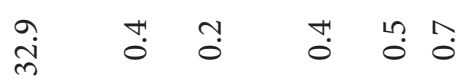

$$
\begin{aligned}
& \text { स艹 }
\end{aligned}
$$

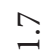
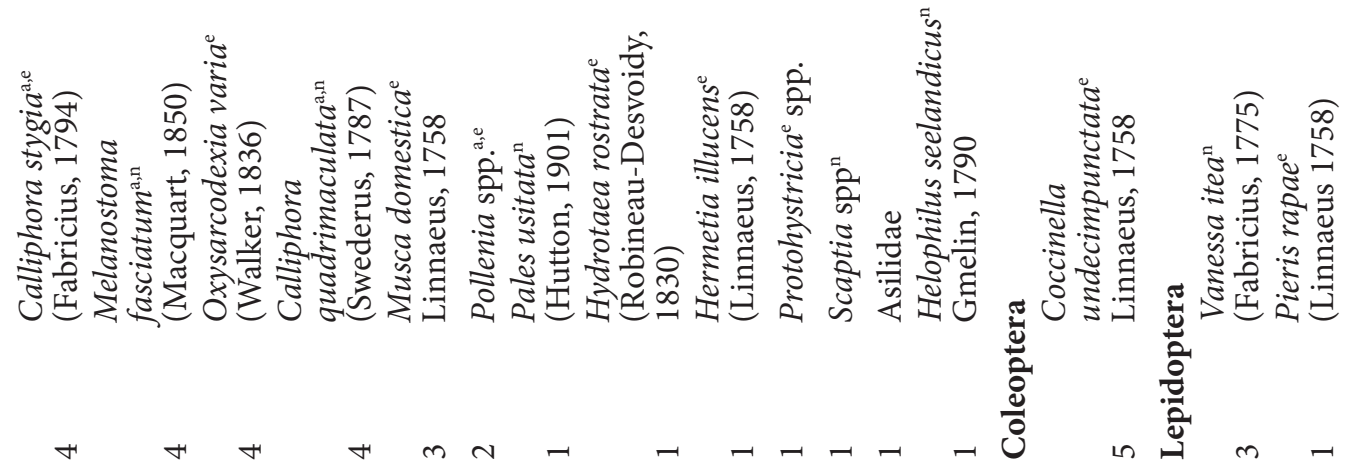


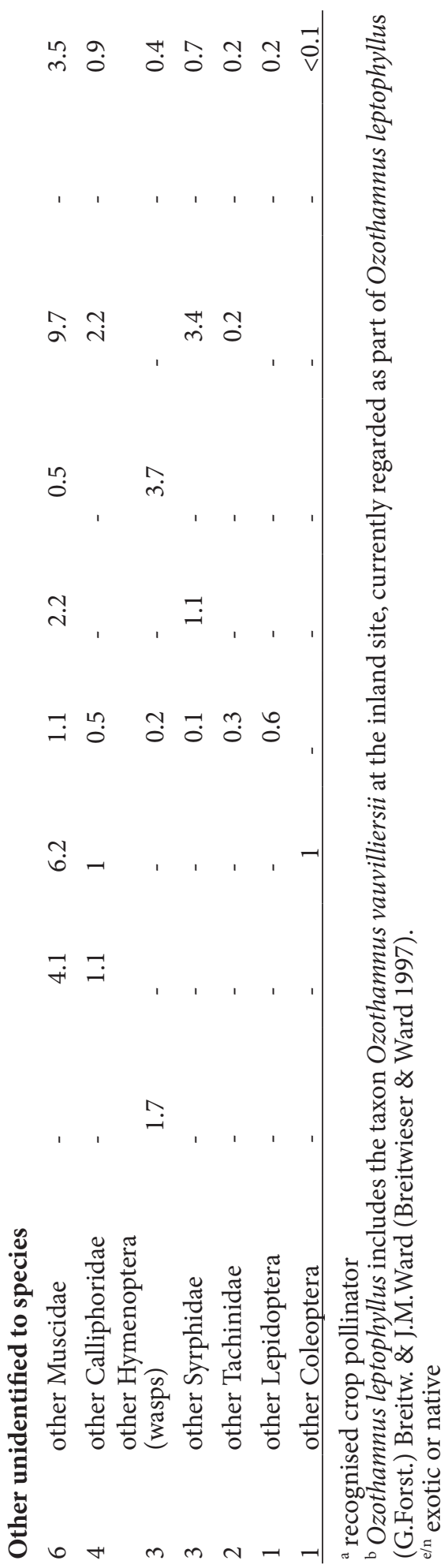

Some tree species attracted many more flower visitors than others, with over half of insect flower visits recorded being on two plant species: Veronica salicifolia (37.1\%) and Cordyline australis (24.0\%). However, this measure combines floral attractiveness and the intensity of flowering in the surveyed season. The latter condition is likely to vary considerably with year and plant age.

\section{DISCUSSION}

The biodiverse plantings at our study sites supported a diverse range of pollinating insects during the spring and summer months, which are critical flowering periods for seed crops that benefit from insect pollination (Howlett et al. 2016). Many of the insects recorded are known crop pollinators and it is plausible that these plantings boost on farm crop-pollinator populations early in the season. The ability of woody plantings to enhance the pollination of adjacent crops has been demonstrated elsewhere (e.g. in the Central Valley of California, USA; Morandin \& Kremen (2013)). It is known that pollinators readily move to and from flowering crops fields (Mesa et al. 2013) and several species (flies and bees) move at least $400 \mathrm{~m}$ into the surrounding landscape (Rader et al. 2011). However, insect species would be expected to vary in their frequency and distance dispersal out from these native habitats, depending on their life cycles, behaviour and the attractiveness of nearby crops outside of native plantings.

It is notable that several of the insect species recorded in the current study were at least as abundant and generalised in their utilisation of flowering plant species as honey bees. Such insects have the potential to provide valuable pollination to crop fields, augmenting and complementing the pollination provided by managed honey bees. At this point in time, the management of wild pollinating species has been poorly explored in New Zealand, although one bee species Leioproctus huakiwi Donovan, 2007 (Donovan et al. 2010) has been successfully established at a site located on The New Zealand Institute for Plant \& Food Research Limited farm 
near Christchurch, Canterbury, New Zealand.

Considerable variation in the size and composition of the pollinator communities across the different tree species was documented. This study suggests that there is potential for enhancing crop pollination through increased pollinator diversity resulting from the presence of native biodiverse plantings on arable farms. In addition to pollinating insects, these plantings may also provide other ecosystem services to cropping systems such as supporting arthropods that predate on pest insects (Howlett et al. 2013a). However, our understanding of the factors that could significantly influence species composition and distribution of arthropod assemblages on arable farms remains limited. The full economic and non-economic value of such plantings requires further study. This includes the diversity of native and exotic insect arthropods they support, aesthetic values, the value and consistency of ecosystem services they deliver to the farm and surrounding land uses. This knowledge is essential to provide grower or community incentive to establish similar plantings in the future.

\section{ACKNOWLEDGEMENTS}

We are grateful to John Evans, David Ward, and Ian Marr for access to their farms. Celine Proirier provided invaluable assistance with the field work. Sam Read (PFR) assisted with project logistics and insect identification. Thanks to Melanie Davidson (PFR) for her valuable inputs in experiment design. We also thank the Foundation for Arable Research who provided critical support for the establishment of the Biodiverse plantings on arable farms. We acknowledge the New Zealand Organisms Register (www.nzor.org.nz/) and NatureWatch NZ (www.naturewatch.org.nz/) as good resources for insect nomenclature and identification. This study was supported by the programme Ministry of Business, Innovation and Employment C11X1309.

\section{REFERENCES}

Breitwieser I, Ward JM 1997. Transfer of Cassinia leptophylla (Compositae) to Ozothamnus. New Zealand Journal of Botany 35(1): 125128.

Davidson MM, Howlett BG, Butler RC, Taylor NM, Walker MK 2015. The influence of shelterbelts in arable farmland on beneficial and pest invertebrates. New Zealand Plant Protection 68: 367-372.

Dicks, LV, Baude M, Roberts SPM, Phillips J, Green M, Carvell, C 2015. How much flower-rich habitat is enough for wild pollinators? Answering a key policy question with incomplete knowledge. Ecological Entomology 40: 22-35.

Donovan BJ, Howlett BG, Walker MK 2010. Relocation and establishment of nesting populations of the native bee Leioproctus huakiwi Donovan (Hymenoptera: Colletidae). New Zealand Entomologist 33: 109-113.

Dynes RA, Burggraaf VT, Goulter CG, Dalley DE 2010. Canterbury farming: production, processing and farming systems.

https://www.grassland.org.nz/publications/ nzgrassland_publication_5.pdf (accessed 13 April 2018).

Fontaine C, Dajoz I, Meriguet J, Loreau, M 2006. Functional diversity of plant-pollinator interaction webs enhances the persistence of plant communities (pollinator diversity and ecosystem sustainability). PLoS Biology 4(1).

Fukuda Y, Moller H, Burns B 2011. Effects of organic farming, fencing and vegetation origin on spiders and beetles within shelterbelts on dairy farms. New Zealand Journal of Agricultural Research 54(3): 155176.

Garibaldi LA, Steffan-Dewenter I, Winfree R, Aizen MA, Bommarco R, Cunningham SA, Kremen C, Carvalheiro LG, Harder LD, Afik O and others 2013. Wild pollinators enhance fruit set of crops regardless of honey-bee abundance. Science 339: 1608-1611.

Howlett BG, Donovan BJ, McCallum JA, Newstrom LE, Teulon DAJ 2005. Between and within field variability of New Zealand 
native flower visitors to onions. New Zealand Plant Protection 58: 213-218.

Howlett BG, Walker MK, Newstrom-Lloyd LE, Donovan BJ, Teulon, DAJ 2009. Window traps and direct observations record similar arthropod flower visitor assemblages in two mass flowering crops. Journal of Applied Entomology, 133(7): 553-564.

Howlett BG, Walker MK, Rader R, Butler RC, Newstrom-Lloyd LE, Teulon DAJ 2011. Can insect body pollen counts be used to estimate pollen deposition on pak choi stigmas? New Zealand Plant Protection 64: 25-31.

Howlett BG 2012. Hybrid carrot seed crop pollination by the fly Calliphora vicina (Diptera: Calliphoridae). Journal of Applied Entomology 136(6): 421-430.

Howlett BG, Davidson MM, Mathers D, Pyke NB 2013a. Hedgerow plants to support crop pollination and pest management. The Weta 46: 3-12.

Howlett BG, Butler RC, Nelson WR, Donovan B 2013b. Impact of climate change on crop pollinator activity in New Zealand. MPI Technical Paper No: 2013/30, Ministry for Primary Industries. www.mpi.govt.nz/ document-vault/4101 (accessed 13 April 2018). 45 pp.

Howlett BG, Lankin-Vega GO, Pattemore DE 2015. Native and introduced bee abundances on carrot seed crops in New Zealand. New Zealand Plant Protection 68: 373-379.

Howlett BG, Davidson MM, Pattemore DE, Walker MK, Nelson WR 2016. Seasonality of calliphorid and sarcophagid flies across Canterbury arable farms requiring pollinators. New Zealand Plant Protection 69: 290-295.

Howlett BG, Evans LJ, Pattemore DE, Nelson WR 2017. Stigmatic pollen delivery by flies and bees: Methods comparing multiple species within a pollinator community. Basic and Applied Ecology 19: 19-25.

Jauker F, Diekötter T, Schwarzbach F, Wolters V 2009. Pollinator dispersal in an agricultural matrix: opposing responses of wild bees and hoverflies to landscape structure and distance from main habitat. Landscape Ecology 24(4): 547-555.

Klein A, Vaissière B, Cane J, Steffan-Dewenter I, Cunningham S, Kremen C, Tscharntke T 2007. Importance of pollinators in changing landscapes for world crops. Proceedings. Biological Sciences, 274(1608): 303-13.

Lentini, PE, Martin, TG, Gibbons P, Fischer J, Cunningham SA 2012. Supporting wild pollinators in a temperate agricultural landscape: Maintaining mosaics of natural features and production. Biological Conservation 149(1): 84-92.

Maldonado MB, Lomáscolo SB, Vázquez DP 2013. The importance of pollinator generalization and abundance for the reproductive success of a generalist plant. PLoS ONE. 2013:8(10):e75482.

Mesa LA, Howlett BG, Grant JE, Didham RK 2013. Changes in the relative abundance and movement of insect pollinators during the flowering cycle of Brassica rapa crops: implications for gene flow. Journal of Insect Science 13: 13.

Morandin LA, Kremen C 2013. Hedgerow restoration promotes pollinator populations and exports native bees to adjacent fields. Ecological Applications 23(4): 829-839.

Ponisio LC, M'Gonigle LK, Kremen, C 2016. On-farm habitat restoration counters biotic homogenization in intensively managed agriculture. Global Change Biology: 22(2). 704-715.

Potts SG, Biesmeijer JC, Kremen C, Neumann P, Schweiger O, Kunin WE 2010. Global pollinator declines: trends, impacts and drivers. Trends in Ecology \& Evolution 25(6): 345-353.

Rader R, Howlett B, Cunningham S, Westcott D, Newstrom-Lloyd L, Walker M, Teulon D, Edwards W 2009. Alternative pollinator taxa are equally efficient, but not as effective as the honeybee in a mass flowering crop. Journal of Applied Ecology 46: 1080-1087.

Rader R, Edwards W, Westcott D, Cunningham S, Howlett B 2011. Pollen transport differs among bees and flies in a human-modified 
landscape. Diversity and Distributions 17: 519-529.

Rader R, Reilly J, Bartomeus I, Winfree R 2013. Native bees buffer the negative impact of climate warming on honey bee pollination of watermelon crops. Global Change Biology 19: 3103-3110.

Rader R, Bartomeus I, Garibaldi LA, Garratt MPD, Howlett BG, Winfree R et al. 2016. Non-bee insects are important contributors to global crop pollination. Proceedings of the National Academy of Sciences 113(1): 146151.

Stavert JR, Pattemore DE, Bartomeus I, Gaskett AC, Beggs JR 2018. Exotic flies maintain pollination services as native pollinators decline with agricultural expansion. Journal of Applied Ecology, 1-10.

Venturini EM, Drummond FA, Hoshide AK, Dibble AC, Stack LB 2017. Pollination reservoirs for wild bee habitat enhancement in cropping systems: a review. Agroecology and Sustainable Food Systems 41(2): 101-142.

Walker MK, Howlett BG, McCallum JA, Wallace AR, Teulon DAJ 2009. Small arthropods as pollinators in a New Zealand pak choi field trial New Zealand Plant Protection 62: 92-98.

Walker MK, Howlett BG, Wallace AR, McCallum JA, Teulon DAJ 2011. The diversity and abundance of small arthropods in onion, Allium cepa, seed crops, and their potential role in pollination. Journal of Insect Science 11: 98. 